\title{
Electronic books: their definition, usage and role in libraries
}

\author{
Susan K. Sawyer \\ Biological Sciences Library \\ University of Queensland Library Service \\ ST LUCIA, QLD 4072, Australia
}

\section{Abstract}

This review examines the literature to establish a definition of electronic books and discovers this is currently related more to hardware and software (viewing technology) than content. It also reports the potential advantages and disadvantages of this format compared to print. It outlines what is currently known about the use of different types of electronic books by users, examining who the most likely users are, detailing what studies reveal about the use and usability of electronic books and the features users want; as well as what factors are inhibiting their use. Additionally the review details what is known about the opportunities and issues arising from the inclusion of electronic books in library collections. It addresses questions regarding the existing models for the use of e-books in libraries, what studies reveal about the realities of their use and what strategies and policies need to be adopted by libraries for their implementation. Finally it examines the degree of take-up of e-books by individuals and libraries and what trends and predictions for the future are emerging with respect to viewing technology, content and role in libraries.

\section{Introduction}

\section{l.i Background}

Hawkins (2000) notes that, despite advances in production and delivery of electronic information, the printed book publishing industry continues to thrive. People read books actively or passively, focussing on one or multiple texts, for a variety of reasons (Schilit 1999). Printed books are a long-lasting cultural icon because they are easy to use, generally portable and resistant to damage. Furthermore, paper and ink have "excellent characteristics for storing and conveying information" (Hawkins 2000) and are readable in a variety of conditions (Darnton 1999). Despite these attractive qualities, printed books have drawbacks - namely, they are costly to produce, store, distribute and update and are difficult to search (Hawkins 2000). With the convergence of computer and telecommunications technology, and the development of global networks, there has been a recent trend in the book industry towards the development of electronic books. These are cheap to manufacture and easy to store, distribute, update and search (Cline 2000; Hawkins 2000). Also, in the library environment, they make economic sense as printing 
costs have pushed the prices of books and journals beyond acquisitions budgets (Darnton 1999; Lonsdale \& Armstrong 2000).

\section{I.ii Definition of an electronic book}

Definitions of e-books differ. Hawkins (2000) states that "an e-book is the contents of a book made available in an electronic form." Lynch (1999) notes how imprecise terminology results in confusion and, both he and Terry (1999), stress the need to distinguish between a digital book (the content) and the viewing technology (hardware and software). Hawkins (2000) outlines three true electronic publishing implementations of the e-book format to which can be added the dimension of proprietary and non-proprietary technology (Crawford 2000). These are tabulated in Table 1 (see appendix I), with examples drawn from the literature.

Morgan (1999) limits the definition of e-books, as opposed to e-texts, to being a hardware/software combination used to read electronic data on a specially designed portable device (i.e. b in Table 1). According to Lynch (1999) and Terry (1999) this would simply be one type of viewing technology - with desktop PCs, notebooks and personal digital assistants (PDAs) being others. Balas (2000) focuses on the software needed to read the book, pointing out that e-texts can be read on any computer system whereas e-books require special reader software. In general, implementations a and $c$ (in Table 1) both result in users reading the electronic book on a desktop or portable computer screen or, if the option exists, printing it out onto paper. However, a move towards more flexible "hybrid" systems is evident with proprietary and general purpose software readers enabling the transformation of a portable computer into an e-book reading device (Burk 2000; Lynch 1999; netLibrary 2000-2001; Terry 1999).

Overall, in discussing a definition of e-books it is apparent that both hardware and software issues of both a proprietary and non-proprietary nature feature more prominently than a definition in terms of content. In general, as Ardito (2000) notes, publishers have been digitising books for reading on screens for more than a decade, though hand held devices for reading e-books are a recent phenomenon. Both modes of use will be considered in this review.

\section{II.iii Advantages and disadvantages of e-books compared to paper}

The main disadvantages for downloadable e-books to standard hardware and those remaining on the provider's web site include reading from PC screens; unattractive formats; and download times dependent on the speed of data lines (Hawkins 2000). Landoni, Wilson and Gibb (2000) and Lynch (1999) add other technological issues such as the dependency on access to unstable telecommunications networks. With books remaining on a subscription Company's web site, is the added 
disadvantage of restricted printing and copying limiting portability (Kirkpatrick 2000).

On the other hand, an e-book is an "integration of the classical print structure with an electronic environment giving additional value added features that paper cannot provide" (Landoni, Wilson \& Gibb 2000). Some of the advantages are timely and cost efficient distribution; the ability to search and interact with the text easily; and widespread accessibility through the Internet (Lynch 1999; O'Leary 1999; Schilit 1999). With a desktop PC, the e-book is not as portable as its print counterpart, but with technological developments resulting in increasingly lightweight computers this is changing. Schilit (1999) cogently outlines benefits that dedicated hand held devices introduce to reading. In addition to those already mentioned, these include: mobile access to large amounts of information; organizing e.g. by annotating; filtering by generating personalised queries; and support for different modes of reading. Some of these advantages can be obtained, when using e-books with other types of hardware, through the use of special reader software.

Even with these potentially attractive functions, the quality of the display, and hence legibility of the content, in both dedicated-device dependent and independent cases is a critical issue (Chaiken et al 1998; Darnton 1999; Hawkins 2000; Kristl 2000; Landoni \& Gibb 2000; Lynch 1999; Terry 1999). Ardito (2000) notes that "displays are improving, but the development of a device that delivers the brightness and resolution of a printed page may be a long time coming." However, Chaiken et al (1998) found that readers were satisfied with the quality of the display of their prototype appliance. These authors consider that the price of suitable high-resolution displays will determine the economic viability of the device. They also note other factors needed to make reading appliances successful including: the weight, orientation and packaging; well-designed user interfaces; and support for both passive and active reading. Landoni, Wilson and Gibb (2000), studying computer screen-based electronic books, were in agreement with the issue of costs to the user being a limiting factor. They also stress that "the quality aspect is crucial because of cognitive issues related to the ability of the reader to use, appreciate and prefer books in electronic format to paper ones."

Overall, there are differing opinions as to the degree reading devices and computer screen-based electronic books stack up against their print counterparts. Hawkins (2000) indicates that current e-book readers are generally lightweight, convenient to carry and easy to use, whereas Ardito (2000) includes the size and weight of portable reading devices amongst the disadvantages. Sottong (1999) outlines technical specifications and comparisons with printed paper indicating that current technology is incapable of producing readable, cheap electronic books. User studies are needed to resolve these issues. 


\section{Design, Usability and Usage of Electronic Books}

\section{II.i Role of Visual Rhetoric in design and usability}

Landoni, Wilson and Gibb (Landoni \& Gibb 2000; Landoni, Wilson \& Gibb 2000 ) investigate the link between paper books and their electronic computer screen-based counterparts in depth. Their work is one of the few studies of electronic books from a content/cultural metaphor perspective that considers the affective/cognitive impact on users rather than considering just viewing technology, which (as outlined in section I.ii), is the main focus of definition.

The first study, the visual book evaluation tested the hypothesis that appearance is an important factor in the effective presentation of information on a screen (Landoni \& Gibb 2000). The results of the experiments suggest that the book metaphor plays an important role in the definition of guidelines for the design of an electronic book. It has to be consistent with, and work according to, the book metaphor. Therefore, when publishing e-books, they propose that the page metaphor should be respected; the logical structure maintained; and titles, pagination, and typographical aspects should be designed carefully to enhance text readability.

These principles are applied in designing and testing a web-based e-book (Landoni, Wilson \& Gibb 2000). A control version of an electronic text was reworked to make it more readily scannable. Data was gathered to test the hypotheses that users of the scannable version would make fewer errors on tasks, report higher subjective satisfaction and that this version would have a higher usability score. They state that all three hypotheses were supported based on the results obtained. However, generalisations made by the authors from such studies using small non-random samples and highly specific text types need to be treated with caution.

\section{II.ii Users and usage of electronic books}

A preliminary review of the available literature reveals much recent hype, activity and comment but still little research, especially in the area of electronic books as opposed to journals (Lonsdale \& Armstrong 2000). College students have been identified as an ideal starting point for studies (Landoni, Wilson \& Gibb 2000; Wearden 1998) for a number of reasons. These include the amount they spend on textbooks; their need for rapid access to large amounts of information; and their level of computer literacy. Portable e-book readers, in particular, offer other features valuable to them; such as portability of a large amount of information and a lightweight, easy to use design (Simon 2001; Tennant 2000). There have also been pilot studies in the use of device independent web-based e-books (Messing 1995; Summerfield \& Mandel 
1999).

\section{II.ii.a Web accessible online books using standard viewing technology}

An early study (Messing 1995) reports on the use of web-based e-books as teaching materials in distance education courses. He stresses the importance of looking at the use of these materials from the client's perspective; and comments on the difficulties in measuring how, and determining why, students use such systems. Hence, to obtain a complete picture it is necessary to employ a variety of strategies. In this investigation electronic log files of all user interactions were created for analysis along with manual ones kept by students. Additionally, students were surveyed, focus groups conducted and a sample was interviewed in depth over the phone. Thus, this study exhibited good use of triangulation methods (Williamson 2000, pp.36-37) to improve reliability and validity.

The results indicated reactions of students to use of electronic books did not conform to theoretical predictions. Regarding the critical issue of readability from computer screens, the studies indicated this to be determined by personal preference. Some students had a clear preference for reading from paper and printed out most of the material (Messing 1995). Surprisingly, the single biggest drawback that students reported was inconvenience of access compared to having a printed copy of the book. This may be because in 1995 even a portable computer wasn't as portable as a book. Also, whilst students commented favourably on the flexibility and interactivity of the electronic materials, the study revealed that these capabilities were not used to their full potential. Hence, training students in the skills required to maximise the potential of this new genre of learning resource is crucial (Messing 1995).

Using a similar mode of access, and also offering users the option to print out the content, Columbia University ran an Online Books Project from 1995 -1999 (Summerfield \& Mandel 1999). One of the purposes of the project was to analyse the user community's adoption of, and reaction to, various on-line books and delivery system features. The results of analysis of data relating to usage (based on hit rates) indicated that "students with a reading assignment that was in the online collection, were looking at the electronic books in some depth" (Summerfield \& Mandel 1999, p.292). The authors suggest that this implied they found some value in this means of access, although they acknowledge the limitations of using hit rates as a measure. They hope that future analysis of log-file data linking user and usage information will reveal valuable insights into user behaviour by department, position and age. Mercer (2000), though mostly studying electronic journal use, also stresses the value of analysing log files and obtaining customised reports on usage by individuals and departments. This information is valuable in identifying user groups requiring training, an issue identified by Messing (1995). 
Summerfield and Mandel (1999) also compared the use of a particular book that was in both print and online format. The results suggest only a minority used the online version. For a class with an assigned reader available in both formats, the majority of students surveyed used their own print copy. Although less conclusive, a survey of the same classes for preferred method of reading produced the same results i.e. that print was preferred. As with Messing's study, these researchers found that willingness to read on-line for extended periods varied from person to person, and they suggest that when their project ended it was still not widespread.

Investigating the features users valued with the online version of a book revealed similar findings to Messing (1995). Immediate access to the text; ease of browsing, navigating and searching; and the ability to manipulate the text were all regarded favourably. The investigations also present data indicating that electronic versions of reference books were particularly well used and received (Summerfield \& Mandel 1999).

Overall both Messing's and Summerfield \& Mandel's studies highlight the need for further research in how students and faculty use, and benefit from access to, electronic books. They also reveal the need to develop reliable measures, and to encourage higher response rates to surveys, to ensure validity of research findings. Conducting similar studies in the context of portable computers and dedicated reading devices, to see if users still felt the need to print out the material, would be valuable.

\section{II.ii.b. Portable reading devices}

Wearden (1998) conducted a study involving American university students to determine their attitudes to hypothetical electronic books, the features most desired, and their willingness to pay. A large majority of this sample were willing to buy devices and either lease or buy electronic texts. Their "right features" were easy navigability through the text, in-built glossaries, searchability, and manufacturer-to-manufacturer compatibility.

A recent preliminary study (Simon 2001), using actual devices, reports the use of four features identified as important in Wearden's 1998 poll. A majority used the glossary lookup and book-marking features, while half used highlighting and less than half annotated content. This small sample was satisfied with the experience, as were users surveyed in university library (Gibbs 1999-2000) and public library (Burk 2000) trials. Both the latter authors note that users liked the backlighting, the ability to change font size, and the portability. In keeping with Simon's findings, the student users also commented favourably on the underlining and dictionary facilities. The public library users were positive about the ability to pack many books into one reader and the opportunity of trying something new. 
Whilst users, surveyed by Gibbs, included cost of the device as a negative factor; significantly, the majority of participants in Simon's study indicated their willingness to purchase the model they had tried. This may be the case in affluent communities, but other commentators (Ardito 2000; Kristl 2000) suggest the expense of these devices is one of the major drawbacks to their widespread use.

\section{II.iii Factors currently inhibiting usage of electronic books}

As well as cost to the user, the authoritative nature of the original may be affected in a move from print to digital works (Ardito 2000). As Hawkins (2000) mentions, e-books can be much more easily updated than their print counterparts; but Ardito (2000) cautions that academic users need to know which edition they have received and whether the electronic text has been accurately maintained. Lonsdale and Armstrong (2000) add other quality control issues, relating to both ensuring the intellectual rigour and authority of the content itself; as well as the crucial issue of visual acceptability. Gibbs (1999-2000) reports the most common negative comments with dedicated devices were related to clarity of screen definition. As noted previously, screen readability is also an issue with users of web-based e-books (Messing 1995; Summerfield \& Mandel 1999). Terry (1999) is one of the few authors to mention the issue of technical support, which is generally limited or non-existent.

Additional concerns of users are interoperability of dedicated devices and reader software; and availability of sufficient titles (Dorman 1999; O'Leary 1999; Simon 2001; Terry 1999). Certainly users in one trial were unsatisfied with the need to borrow a particular device for a particular title (Gibbs 1999-2000). Furthermore, e-book suppliers operate independently with differing approaches to encryption to prevent copying of their books (Barnard 1999). This copyright protection raises issues for users as to whether they will be able to do the same things with e-books (lend, copy sections, replace) that they currently do with printed ones (Lynch 1999). The ability to be able to print out the book for portability or extended reading purposes is also of concern to users (Messing 1995; O'Leary 1999).

\section{E-books and libraries}

\section{III.i. The context}

Libraries have traditionally collected printed books and journals to provide access to educational, literary and recreational texts; and to act as a repository of this material for posterity. Hence, they play a key role in the traditional information chain (Darnton 1989 quoted in Ferguson 1994) and have been one of the main vehicles for "the mass distribution of books directly to readers" (Barnard 1999). Additionally, they have been 
committed to the public good and equity of access to information. The move to digital information resources in general threatens this role, as libraries no longer have the same kind of control of the material (Coyle 2000). Hence, Tennant (2000) poses the pertinent question "how will e-books and e-book readers fit into the mix of library collections and services?"

\section{III.ii Models for collection management of electronic books and their use in libraries}

A number of libraries are already in the process of electronic book collection development and running pilot projects in their use (Ardito 2000; Fialkoff 2000; Hawkins 2000). As e-books come in devicedependent formats or device independent formats (Tennant 2000), several models can be described. The models equate with the e-book publishing models and their degree of openness outlined in Table1. Hence, libraries can opt for any, or all, of the following models: a) open access web-based books using standard hardware/software systems; b) software-based systems; c) hardware-based distribution systems; and d) web server-based distribution systems. They are described in Table 2 (see Appendix II) with some examples of their reported use in libraries.

Librarians (Bryant 2000; Fialkoff 2000) have raised concerns regarding the appropriateness of these models for library e-book collection management and service delivery. Lynch (1999) stresses the importance of the library community discussing what they want from digital books. He notes that the models outlined in Table 2 (except the first) all emulate physical books in a library with one person at a time viewing, or borrowing, a particular copy. This is very different from site licence to digital content; the primary model for electronic information access over recent years (Flowers 1999; Lynch 1999). The latter allows simultaneous users for an additional fee, permits email delivery of content, and gives users the option to print out or download the text. Both Messing's (1995) and Summerfield and Mandel's studies (1999) indicate that ready access from any location at any hour is a valued feature of the online format. This positive feature is applicable to a site licence model of electronic book access, but would not be applicable to the physical book emulation models, without purchasing multiple copies of the required titles or devices.

Despite these concerns, Barnard (1999) comments on the variety of opportunities that exist for enhancing service to library clientele by combining e-texts and electronic reading devices. These include lending customised packages of electronic texts, inter-library loan requests delivered on a reading device, and electronic reserve delivery to students (Barnard 1999; Burk 2000; Gibbs 1999-2000; Morgan 1999). Likewise, a number of service possibilities have been noted for pseudo-circulating electronic book services including on demand access (provided sufficient 
copies of a title have been purchased), timely inter-library and intercampus loans; and support for distance education and remote users (Albanese 2000b; Anon 1999b).

\section{III.iii Issues for consideration and strategies for successful implementation}

Advantages of e-books for libraries include the technical ability for a single copy to be made accessible to multiple users; their durability; their use in preservation; the fact they don't go out of print; their ability to support distance learning; and their potential to provide users with access 24hours a day/7 days a week (Ardito 2000; Fiander 2000; Hawkins 2000). Marcinko (2000) notes other reasons to allocate some of the budget to e-book collection development. These include the potential to reduce costs associated with maintaining growing print collections, ease of update of rapidly changing material, their suitability as reference books, and improved turnaround time on book circulation. Libraries also have a tradition of experimentation in new ways to meet evolving needs (Marcinko 2000); as well as a commitment to providing equity of access to information in all formats (Burk 2000).

The multiple access advantage is defeated by the "pseudocirculating" (Crawford 2000) models of lending; as is the potential for 24/7 access if the only copy of the book is already on loan to one client (Albanese 2000b; Flowers 1999). Gibbs (1999-2000) notes the necessity to purchase multiple copies of the same title to load on different reading devices. The preservation advantage is disputed by Sottong (1999) who outlines technical arguments for questionable data permanence of electronic media in comparison to paper. He also raises the issue of potential obsolescence in the viewing technology, thus making the information inaccessible.

The issue of ownership raises concern (Anon 2001b; Ardito 2000; Bryant 2000; Fiander 2000; Flowers 1999; Hawkins 2000; Lynch 1999). As Lynch (1999) notes, libraries will need to "ensure that they have copies of works that can be incorporated into permanent collections for continued access". Subscriptions to an electronic book collection are problematic when the library decides not to renew. In a print world the library keeps whatever materials its payments have already purchased, but in a digital one access tends to be lost. For a price netLibrary does allow perpetual access as an option (O'Leary 1999; Rogers 2000b). With dedicated devices, Gibbs (1999-2000) expresses concern as to whether vendors will resupply titles tied to a damaged machine at no extra cost.

With e-books residing on web servers, and the current ability of technical copyright protection systems (Anon 2001b; Lynch 1999), the need to negotiate licence agreements accommodating fair use for research and study is circumvented (Bryant 2000; Flowers 1999). Dillon (2000) 
highlights that insufficient attention is given to user needs and that the "excessive and intrusive digital rights management of e-books could decrease their value to libraries as a means of permanently communicating the knowledge contained in them".

As mentioned previously lack of interoperability and open standards are issues of concern for users. This state of "fragmentation" (Dillon 2000) is also of concern to libraries. With "no common access or delivery method" (Fiander 2000) libraries are left with a number of models on which to base service delivery, as outlined in Table 2. As all are limited not only by interoperability but also by the lack of available content, libraries need to adopt several models to provide adequate service to their clients. Indeed, Gibbs (1999-2000) mentions the complementary nature of subscribing to netLibrary in addition to acquiring dedicated reading devices. This, however, means the library needs to put in place appropriate administrative procedures to deal with both. The potential for saving staff time with one service is negated by the labour intensive nature of the other; and the library must incur the costs of complex licencing negotiations arising from both.

Despite the potential for saving money, by reducing the overhead and infrastructure costs associated with growing print collections (Albanese 2000b), costs are also an issue (Bryant 2000; Fialkoff 2000; Gibbs 1999-2000). Concern exists with services such as netLibrary regarding the costs and pricing structure, with ongoing access fees in addition to purchase costs for books (O'Leary 1999). With dedicated reading devices, as well as the need to invest in special hardware, Fialkoff (2000) notes the problem of device dependency resulting in hundreds of dollars worth of books residing on a machine useable by only one patron at a time. Sottong (1999) believes reading appliances will become obsolete resulting in funds being wasted when libraries are forced to buy replacements.

A number of commentators (Albanese 2000b; Gibbs 1999-2000; Lynch 1999), question the policies of content providers, like netLibrary, regarding the privacy of library clients' and usage data compiled when users log onto their web site.

This collision between user's rights to read anonymously as opposed to publisher's interest in gaining business intelligence requires libraries to look closely at agreements they sign with e-book vendors (Anon 2001b).

Lonsdale and Armstrong (2000) highlight the problem of bibliographic access, which is important to librarians engaged in collection management. From their study of the literature, they found this issue had received little attention. Whilst the need to extend legal deposit laws to include web monographs was identified, no action has been taken. Compounding on this, major publishers of trade bibliographies do not currently include web monographs in their bibliographical databases and, 
according to their survey, it was often difficult to identify electronic titles from publishers web sites.

Overall, Dillon (2000) notes the challenge to incorporate electronic books into existing routines and believes their format and functionality make them a "new breed of information species". Indeed, experiences with device dependent and independent books led his team of librarians to formulate a set of guiding principles for the acquisition of e-books. These cover their integration with other workstation resources, their user-friendliness, their persistence in terms of both content and network accessibility and their compatibility with existing library technological infrastructures.

Highly significant in these guidelines is the importance attached to no proprietary hardware or software being needed to read, or access, the book and the ability to use them both on and offline (Dillon 2000). This highlights the vital role of open standards and gives a cautionary note to libraries engaged in lending proprietary portable reading appliances, loaded with proprietary titles, despite positive responses from users. However, as Lynch (1999) notes "if important materials are available only for one specific e-book reader, librarians will have some hard decisions to make."

Lamont (1999) stresses that although the technological, administrative and cost considerations of new services should not be discounted, it is human factors that will determine the success or failure of a project. A broad user base is vital to justify funding and lend legitimacy and credence. Managing user expectations, in a digital environment, is challenging and requires knowledgeable, flexible, staff as well as a supportive, informed, management. To these ends, Mercer (2000) stresses the vital importance of measuring usage statistics. Whilst her study focuses mainly on electronic journals, there are a number of points equally applicable to e-book collection development. These include the importance of having usage statistics for both print and electronic formats of the same title; and the need to negotiate with vendors to ensure the statistics, not only for purchasing or cancellation decisions are available, but also those informing on users' habits, are provided to support development of associated services.

\section{The future of electronic books - trends and predictions}

\section{IVi. Viewing technology}

Ardito (2000) comments that "e-publishers have a long way to go before they completely satisfy print book lovers", "though industry players believe ubiquitous use of e-books is only a matter of time" (Maack 2001, p.60). Some large academic libraries (General Libraries 2000) are committed to further development of web-based e-book access via 
e-book vendors, though both Sottong and Hage (Kristl 2000) believe the future will be in hand held devices.

One Australian industry player has indicated that both computer-based and dedicated-device based systems will be used for different purposes (Maack 2001, p.60). Users will prefer a PC for active reading, whereas for recreational (immersive) reading a dedicated-device will be needed. A recent consumer survey (Anon 2001a; Maack 2001, p.58) revealed 28\% of respondents were willing to engage in recreational reading on an e-book device and $66 \%$ would read a reference work on a computer. However, only $12 \%$ said they were likely to buy an e-book or a reading device in the next year. Despite this, Maack (2001, p.58) notes that e-book manufacturers and e-publishers remain confident and reports that one study predicts 28 million device users by 2005 .

There is a question as to which type of device will be adopted. E-books and other texts can be read on a PC, laptop, personal digital assistant (PDA) or dedicated reading device. PDAs are emerging as competition to the dedicated reader (Ditlea 2000; Greiner 2000; Maack 2001). As far as the reading of articles is concerned, the results of a recent poll support this viewpoint, with PalmOS and Pocket PC devices proving more popular than dedicated reading devices (Nuvomedia 2001).

Schilit (1999) notes that "although paper books are a functional and cultural icon, reading appliances as tools that improve the ability to learn and manage written information will prove invaluable for knowledge workers." The technology is being pitched at students and the travelling businessperson (Maack 2001, p.60). One study found 54\% of the business travellers surveyed left books behind, due to lack of luggage space; and $75 \%$ felt electronic access to books would be useful (Anon 1999a). Surprisingly, few commentators focus on the potential advantages for people with a range of disabilities. Gibbs (Gibbs 1999-2000) mentions the advantage of the ability to increase the font size for the print-disabled and the value of easy page turning for people with physical disabilities.

Overall, there are still unanswered questions about how the e-book and reading device market will develop (Bryant 2000; Maack 2001). High-resolution displays; attractive pricing; improvements in portability and interoperability; and ability to view multimedia may be necessary to encourage widespread use (Ardito 2000; Barnard 1999; Bryant 2000; Cline 2000). Research and development is addressing some problems to enhance the functionality of newer models (Hawkins 2000). Overall, commentators believe in the short term, advances in viewing technology will drive the evolution of the e-book, though in the long term, it will be content that matters (Cline 2000).

\section{IV.ii. Content}


Bryant (2000) reports on a congress at which most industry players conceded that quantity of content had not yet reached critical mass. It was predicted that 2001 would be the turning point following the release of open formatting standards through the Open eBook Forum (OeBF). These should increase the amount and interoperability of content, whilst still allowing manufacturers to encrypt it to protect copyright (Ardito 2000).

There is also interest in the types or genres of material published as e-books. As Cline (2000) comments "the market is currently somewhat bifurcated between very popular materials and the highly technical." Certain genres have been successful in electronic form and are already replacing their print counterparts - namely, bibliographies, indexes, dictionaries, encyclopedias, directories, and technical manuals (Anon 2001b; Lynch 1999; Tennant 2000). Summerfield and Mandel's (1999) study clearly found that reference books were used more heavily on-line than in print. With such texts, their readers want to find and read relatively short chunks and this is a key situation in which producing electronic books is deemed appropriate by researchers (Landoni \& Gibb 2000). There is an industry perception that the student textbook market will be sizable (Maack 2001, p. 61) and there are already a number of electronic textbook trials underway (Anon 2000; Minkel 2000). However, little work has been done to determine how other popular print genres, particularly fiction, can evolve successfully into new digitally based formats (Lynch 1999). Burk (2000) identifies a potential audience for e-books as readers of series books, or books in a particular genre. However, the industry (Maack 2001, p.61) believes that fiction is one of the types of e-books least likely to be taken up in the short term.

\section{IV.iii. Role of Libraries}

Cline (2000) notes comments by Gibbs that it is somewhat early to determine the impact of e-books on a library collection, though the indications are that they have been reasonably successful to this point. However, as outlined previously, issues of access, preservation, ownership, copyright and fair use, cost, privacy, standards, bibliographic control and adequate content are critical. There is concern over the appropriateness of e-book acquisition and service delivery models and Bryant (2000) mentions the comments of Davenport regarding the lack of "library models either in terms of business prototypes for selling to libraries or in terms of an understanding of the public good libraries provide."

Terry (1999) highlights the need for libraries to assess client interest and usage levels to implement e-books successfully. Preliminary (but inconclusive) studies suggest scholars' preference for print over web-based PC format (Summerfield \& Mandel 1999), especially if the book is a major course text or needed for research purposes. However, 
this may be a reflection of the desktop hardware and software technology used, since other studies indicate users' enthusiasm for content delivered on dedicated reading appliances (Burk 2000; Gibbs 1999-2000; Simon 2001). Furthermore, despite offering very restrictive print options, the web-based pseudobook circulating service, netLibrary, is proving successful. Marketing strategies aimed at both the academic and public library sectors (Breeding 2000; Quint 2000) have resulted in libraries, corporations, US library networks and publishers signing up for service (Breeding 2000; Kirkpatrick 2000; Minkel 1999; Rogers 2000b). It has also successfully targeted large consortia (Flowers 1999), library suppliers (Anon 1999b) and library software vendors (Breeding 2000; Rogers 2000a).

Breeding (2000) stresses the importance of cooperation between library automation vendors and content providers to assist libraries in handling an increasing array of electronic media. Distributors of e-books that operate in the library market are more likely to bring librarians, and their concerns, into the planning for new formats (Fialkoff 2000). Davenport (quoted in Bryant, 2000) hopes to "incubate new products and a new attitude in a library industry working group that she is setting up under the auspices of the OeBF". There are indications that library book vendors also want interested parties to work together (Cline 2000; Marcinko 2000). "Consolidation of orders, invoicing, facilitating the flow of information between publishers and libraries, and the possibility of a new form of approval plan are some of the services which could be of benefit" (Cline 2000). NetLibrary is working towards providing such services as well as towards a more open one-to-many lending model (Albanese 2000b).

With wrangling over copyrighted material, the provision of access to copyright free texts through public domain digital libraries like University of Virginia (UVA) Etext Centre and the Internet Public Library is important (Albanese 2000a; Crawford 2000). It is noteworthy that netLibrary has now formed an alliance with UVA to preserve historic texts in digital form and distribute them to libraries, some for free, but some only by subscription (Quint 2000). Further, adding to its seamless services, this company is reported as hoping "to allow libraries to load records to enable users to preview information on books and then purchase them on the netLibrary site" (Breeding 2000) as well as "ultimately having printon-demand" (Albanese 2000b).

Marcinko (2000) indicates many issues and questions remain with regard to funding and budgeting e-book acquisition, how selection decisions will be made, and what staff and user training issues will need to be addressed. The issue of open standards allowing interoperability is a critical issue and may result in some libraries holding back until it is addressed (Lynch 1999). However, Burk (2000) and Hage (in Kristl 2000) believe firmly that libraries should play a part in bringing this new format 
to the public in response to customer demand and as a reflection of their commitment to equity of access.

Gibbs (1999-2000) raises the question as to whether electronic book technology will mean the end of the library. She believes the traditional book will always have a place in academic libraries. Undoubtedly, it will take years to digitise all the existing materials that scholars depend on for research, let alone produce electronically the approximately 100,000 books that are published in print form in English annually (Albanese 2000b).

\section{Conclusion}

The definition of what constitutes an electronic book is still in a state of flux. Both content and viewing technology are components of an e-book. Currently, the focus is on the latter with the quality of the display being a critical component and the issue of open standards pivotal to its future development and adoption. However content should not be overlooked; the print book represents an important cultural icon and, despite the value-added functions possible with an electronic format, the maintenance of the book rhetoric is an important concept in the development of good electronic books in order for psycho-social acceptance by users to occur.

This review reveals some important findings from preliminary user studies with both web-based e-books, viewed on standard hardware and software, and with those read on dedicated reading appliances with software aimed at improving readability. A key finding for books viewed with the former is that personal preference and length affects the extent to which users are unsatisfied with the screen readability, and are thus likely to print out an electronic text. Where printing is an option, the extent of conversion to paper format is quite high, and there is still a preference for print books for texts requiring active reading. Features users value with online electronic books include immediate access to the text; ease of browsing, navigating and searching; and the ability to manipulate the text. For books read using dedicated devices, the literature indicates that users are generally satisfied with the experience. Popular features include backlighting, the ability to change font size, and portability. Negative reactions are reported regarding the key issue of readability and screen clarity, the inability to read graphics, the limited availability of content, the lack of interoperability and in some cases the cost.

However, it should be borne in mind that the majority of these studies involve small (often non-random and highly specific) samples and/or surveys with low response rates and thus limitations are imposed on the reliability and generalisability of the findings. Furthermore, some reports lack any description of the composition or size of the sample population and clear analysis of the results. More rigorous research is needed to 
establish a more accurate picture of user behaviour and usability of e-books. It needs to include detailed quantitative analysis of log files to track what users do with e-books and qualitative in-depth interviews to gain a deep understanding of user behaviour and user needs. Ways of encouraging higher response rates to surveys need to be found to improve validity, and research should aim to include break down by age, educational background, and degree of familiarity with PCs to give insight into the factors affecting findings.

Conducting and communicating research is vital for libraries that in the near future will be allocating portions of their squeezed budgets to purchase of viewing technology and content. For example, should libraries subscribe to Internet e-book vendors that don't give users the option to print, or will charge them additional fees for this service, when there is still a clear preference amongst some users to do extended reading in this format? Should libraries purchase proprietary reading appliances that may be come obsolete quickly or should they wait until open standards enable books to be downloaded to any device or portable computer?

At the moment viewing technology is a limiting factor but in the future content will become paramount. Currently, the literature indicates that certain genres are successful in electronic form and are replacing their print counterparts. There is confidence that reference and educational materials will prove to be a viable market for e-books. Although some works of fiction now only exist in electronic form, there has been surprisingly little research and market analysis as to how this popular print genre can evolve successfully into a digital format.

Despite much recent media hype, there appears to be only limited take up of e-books by individuals and libraries, and the market is still ill defined. Users and libraries are concerned about issues such as access, preservation, ownership, copyright and fair use, standards, costs, privacy, quantity of available content and bibliographic control. As more libraries venture into e-book lending, the impact these issues have on collection development policies, budget considerations and client service will become increasingly important.

Control of content is an important feature of the electronic book world. With provision of seamless services, to the apparent benefit of libraries, offered by e-book distributors, perhaps a note of caution should be sounded. One wonders if libraries are in danger of becoming a "try before you buy" marketing and sales channel for such businesses. As noted in the literature, libraries need to discuss what they want from digital books and whether the models for collection development currently on offer are appropriate to the needs of their clients. Opportunities to collaborate with industry to address issues of concern must be sought to ensure libraries can continue to play a role in communicating information, and acting as 
repositories of knowledge, for the benefit of humankind.

Appendix I: Table 1: E-book publishing models and their degree of openness

\begin{tabular}{|c|c|c|}
\hline $\begin{array}{l}\text { E-book publishing } \\
\text { model }\end{array}$ & Openness & Examples \\
\hline \multirow[t]{2}{*}{$\begin{array}{l}\text { a) Downloadable } \\
\text { e-books from a } \\
\text { web site to a user's } \\
\text { desktop or portable } \\
\text { computer. }\end{array}$} & $\begin{array}{l}\text { Non-proprietary } \\
\text { public domain } \\
\text { e-books (Crawford } \\
2000 \text { ) }\end{array}$ & $\begin{array}{l}\text { ASCII texts available for free by ftp from Project } \\
\text { Gutenberg, and } \\
\\
\text { html files which can be viewed with a web } \\
\text { browser and downloaded to a user's own hard } \\
\text { disk or printed out e.g. the free texts available } \\
\text { through the University of Virginia Etext Center } \\
\text { (Albanese 2000a), and one section of the } \\
\text { Internet Public Library (Crawford 2000) }\end{array}$ \\
\hline & Proprietary & $\begin{array}{l}\text { Those requiring special software to be viewed } \\
\text { or printed out after download to the users PC } \\
\text { e.g. Glassbook Reader (Balas 2000)). With this } \\
\text { software a "hybrid" a/b system is possible as } \\
\text { e.g. the book can be downloaded and read on a } \\
\text { notebook with the display rotated by } 90 \\
\text { degrees so the computer can be held like an } \\
\text { open book (Burk 2000) . }\end{array}$ \\
\hline \multirow[t]{2}{*}{$\begin{array}{l}\text { b) Books } \\
\text { downloaded to a } \\
\text { dedicated e-book } \\
\text { reader }\end{array}$} & $\begin{array}{l}\text { Proprietary e-book } \\
\text { devices (locked } \\
\text { e-books) }\end{array}$ & $\begin{array}{l}\text { These are hand-held, battery-powered devices, } \\
\text { e.g. the Rocket e-Book, SoftBook Reader, and } \\
\text { Franklin eBookman) (Ardito 2000; Balas 2000; } \\
\text { Cline 2000; Crawford 2000; Gibbs 1999-2000; } \\
\text { Terry 1999). These devices vary but they all } \\
\text { share certain features that improve the reading } \\
\text { experience: optional backlighting; adjustable } \\
\text { type size and font; bookmarking, hyperlinking } \\
\text { and annotating capabilities; and portability of } \\
\text { multiple titles (Burk 2000; Terry 1999) . They } \\
\text { vary as to their weight, capacity, battery power, } \\
\text { availability of colour, price and method of } \\
\text { downloading (Cline 2000; Crawford 2000) . }\end{array}$ \\
\hline & $\begin{array}{l}\text { Open standard } \\
\text { e-books }\end{array}$ & $\begin{array}{l}\text { An open standard allows any text to reside on } \\
\text { any reader. Potential reading devices for open } \\
\text { e-books include desktop PCs, notebooks, } \\
\text { palmtops and other handheld personal digital } \\
\text { assistants (PDAs) as well as locked readers } \\
\text { (Ardito 2000; Crawford 2000). Lynch (1999) } \\
\text { and Terry (1999) note the emergence of } \\
\text { general purpose software book readers (e.g. } \\
\text { Microsoft Reader with ClearType) that run on } \\
\text { general-purpose desktop and portable } \\
\text { computers turning them into non-proprietary } \\
\text { open e-book-reading appliances. }\end{array}$ \\
\hline $\begin{array}{l}\text { c) Internet-based } \\
\text { subscription } \\
\text { e-book services } \\
\text { where the e-book }\end{array}$ & $\begin{array}{l}\text { Proprietary, } \\
\text { circulating } \\
\text { psuedobooks } \\
\text { (Crawford 2000) }\end{array}$ & $\begin{array}{l}\text { An example is netLibrary (Albanese 2000b; } \\
\text { Anon 1999b; Balas 2000; Breeding 2000; } \\
\text { Crawford 2000; Flowers 1999; Gibbs } \\
\text { 1999-2000; Kirkpatrick 2000; Marcinko 2000) . }\end{array}$ \\
\hline
\end{tabular}




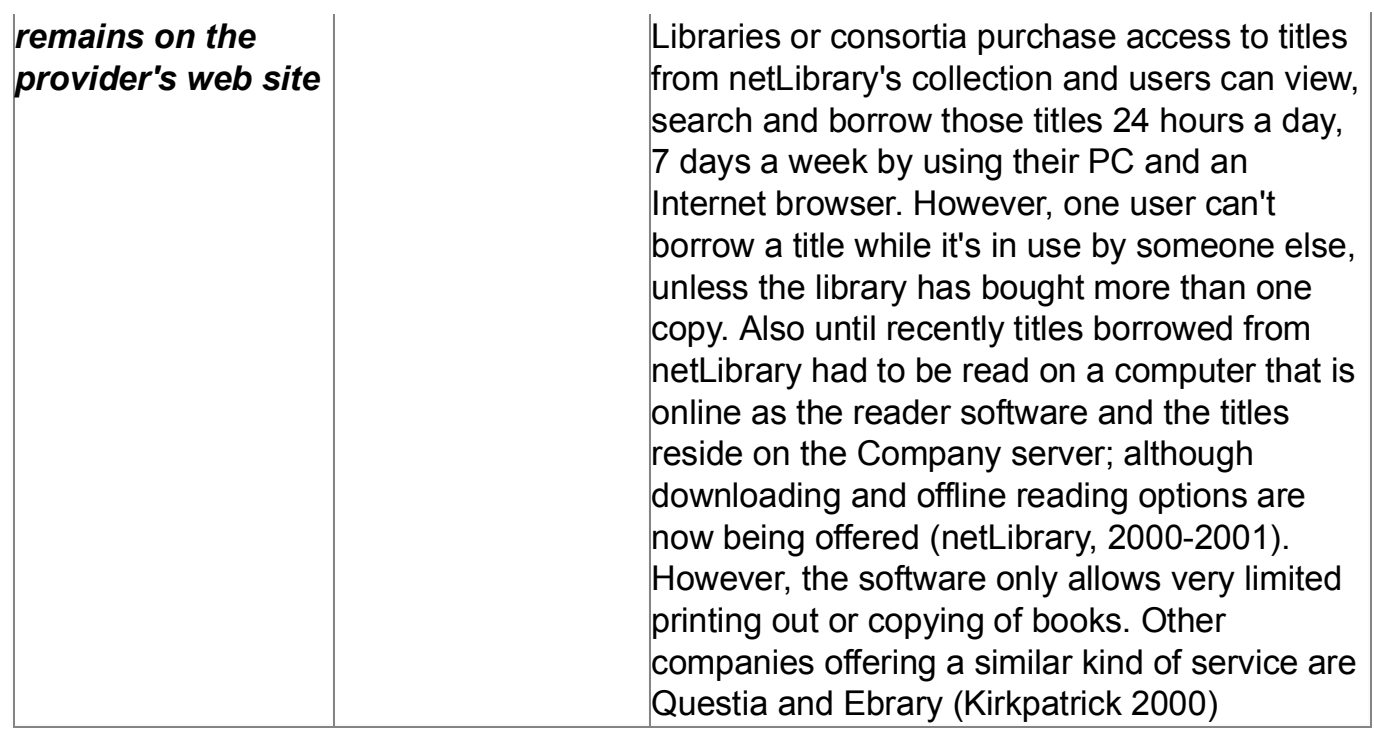

Appendix II: Table 2: Models for collection management of electronic books and their use in libraries.

\begin{tabular}{|c|c|c|c|}
\hline $\begin{array}{l}\text { E-book service } \\
\text { delivery model }\end{array}$ & Description & Use in libraries & Advantages/Disadvantages \\
\hline $\begin{array}{l}\text { a. Open access } \\
\text { web -based books } \\
\text { using standard } \\
\text { hardware/software } \\
\text { system }\end{array}$ & $\begin{array}{l}\text { Libraries can } \\
\text { organise access } \\
\text { to sites in the } \\
\text { public domain } \\
\text { such as Project } \\
\text { Gutenberg and } \\
\text { the University of } \\
\text { Virginia (UVA) } \\
\text { Etext Center } \\
\text { providing free use } \\
\text { of non-copyright } \\
\text { restricted texts } \\
\text { using standard } \\
\text { hardware and } \\
\text { software. }\end{array}$ & \begin{tabular}{l} 
Albanese \\
(2000a) notes use \\
of free access to \\
copyright free \\
books through the \\
UVA Etext Center \\
is surging. A broad \\
range of users, \\
from recreational to \\
school and \\
university students \\
from more than \\
100 countries have \\
downloaded \\
e-books. This site \\
is accessed some \\
90,000 times a day \\
by approximately \\
25,000 users. \\
\multicolumn{1}{c}{ Summerfield } \\
and Mandel (1999) \\
report on the \\
Columbia \\
University Online \\
Books Project \\
which ran from \\
$1995-1999$. The \\
on-line books were \\
accessible \\
simultaneously to \\
multiple library \\
clients through the \\
Web using a \\
desktop PC with
\end{tabular} & $\begin{array}{l}\text { Allows multiple users to } \\
\text { access copies of the text } \\
\text { simultaneously, print it out, } \\
\text { download it or copy it. } \\
\text { Requires no investment in } \\
\text { additional hardware and } \\
\text { software. } \\
\text { E-books can be } \\
\text { downloaded to PCs and PDAs } \\
\text { and comfortable reading } \\
\text { experience obtained through } \\
\text { Microsoft's Clear Type } \\
\text { Technology. } \\
\text { Accommodates a reported } \\
\text { preference for some users for } \\
\text { printing out the material } \\
\text { (Messing 1995; Summerfield \& } \\
\text { Mandel 1999) . } \\
\text { Limited by the lack of } \\
\text { available content. }\end{array}$ \\
\hline
\end{tabular}




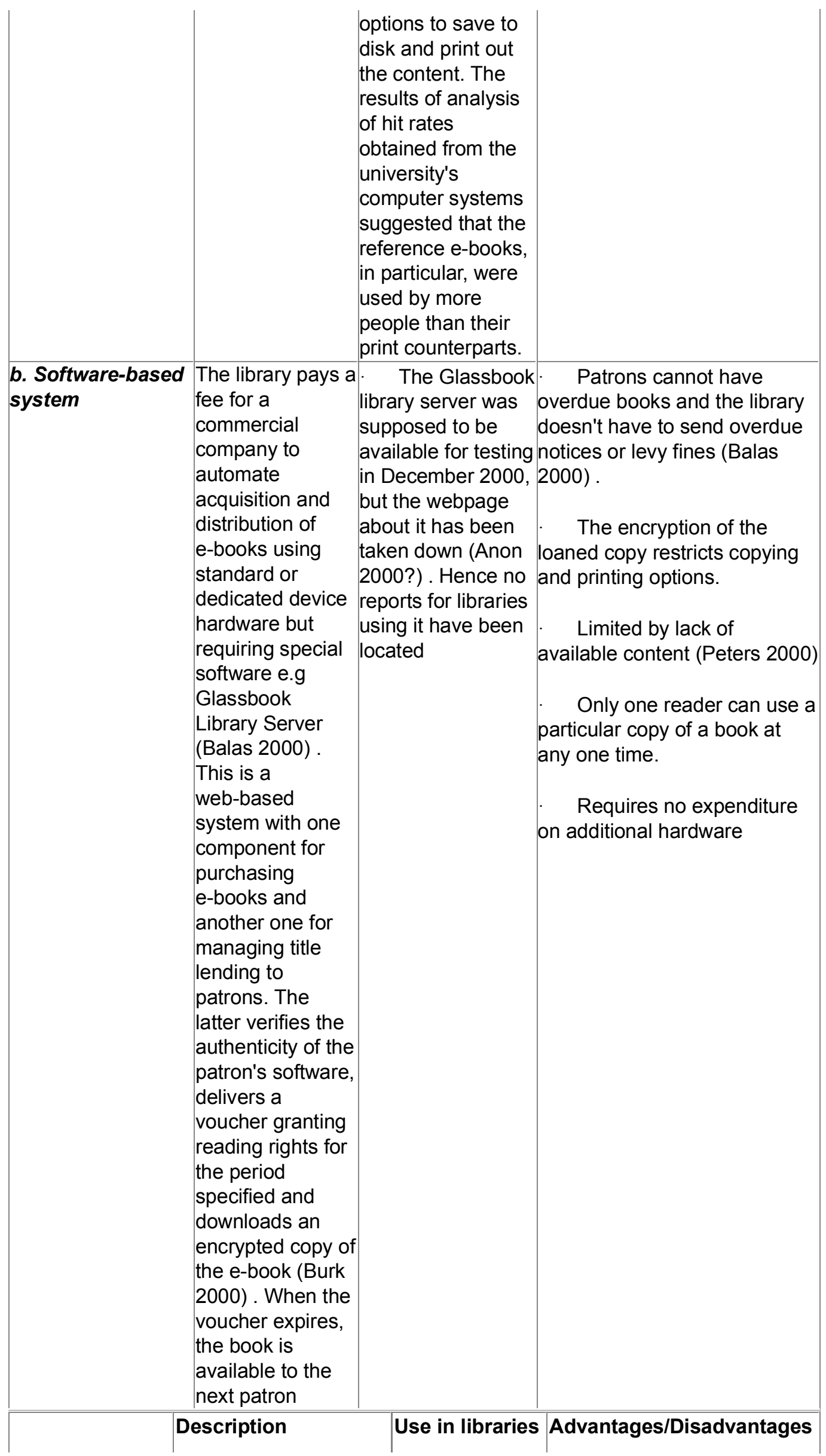




\begin{tabular}{|c|c|c|c|}
\hline $\begin{array}{l}\text { E-book service } \\
\text { model }\end{array}$ & & & \\
\hline $\begin{array}{l}\text { C. } \\
\text { Hardware-based } \\
\text { book } \\
\text { distribution } \\
\text { systems }\end{array}$ & $\begin{array}{l}\quad \text { The library } \\
\text { acquires one or more } \\
\text { models of handheld } \\
\text { devices and loads } \\
\text { these with e-books } \\
\text { from the respective } \\
\text { vendor (Burk 2000; } \\
\text { Gibbs 1999-2000), or } \\
\text { with material it has } \\
\text { prepared itself in the } \\
\text { appropriate format } \\
\text { (Morgan 1999; Simon } \\
\text { 2001). } \\
\text { - Or the library waits } \\
\text { until open e-book } \\
\text { standards have been } \\
\text { developed and become } \\
\text { more widespread } \\
\text { enabling users to } \\
\text { download texts } \\
\text { purchased from a } \\
\text { range of vendors on to } \\
\text { a computer or a } \\
\text { personal digital } \\
\text { assistant. This may } \\
\text { give more options for } \\
\text { printing out or copying } \\
\text { text. }\end{array}$ & $\begin{array}{l}\text { Preliminary } \\
\text { findings for use } \\
\text { of e-books } \\
\text { linked to } \\
\text { proprietary } \\
\text { portable reading } \\
\text { devices include: } \\
\quad \text { The } \\
\text { comments of } \\
\text { Gibbs } \\
\text { (1999-2000) } \\
\text { describing a trial } \\
\text { of e-book } \\
\text { readers (Rocket } \\
\text { eBooks and } \\
\text { SoftBooks) at } \\
\text { the North } \\
\text { Carolina State } \\
\text { University } \\
\text { library. }\end{array}$ & $\begin{array}{l}\text { Most problems encountered } \\
\text { were in the areas of } \\
\text { technology, library service } \\
\text { administration and human } \\
\text { factors. Table } 3 \text { in Appendix } 3 \\
\text { summarises the issues } \\
\text { mentioned. Some key points } \\
\text { are: } \\
\quad \text { Library must purchase } \\
\text { and manage additional } \\
\text { hardware. } \\
\quad \text { Content is tied to a } \\
\text { specific device so more than } \\
\text { one type may need to be } \\
\text { purchased/borrowed. } \\
\text { Only one patron can use } \\
\text { a device/title at a time. } \\
\text { Encryption software } \\
\text { prevents any copying or } \\
\text { printing out of the text. } \\
\text { limited } \\
\text { labour intensive } \\
\text { time-consuming } \\
\text { lable content is } \\
\text { anging devices is }\end{array}$ \\
\hline $\begin{array}{l}\text { d. Web } \\
\text { server-based } \\
\text { distribution } \\
\text { system }\end{array}$ & $\begin{array}{l}\text { The library can } \\
\text { subscribe to a web } \\
\text { based "circulating } \\
\text { pseudobook" (Crawford } \\
2000 \text { ) service such as } \\
\text { that offered by } \\
\text { netLibrary. NetLibrary's } \\
\text { total catalog of books } \\
\text { now stands at over } \\
32,000 \text { (Kirkpatrick } \\
2000 \text { ) and the site also } \\
\text { gives access to } 2,500 \\
\text { public domain titles } \\
\text { available for free (Balas }\end{array}$ & $\begin{array}{l}\text { Carolina State } \\
\text { University } \\
\text { Libraries not } \\
\text { only trialed } \\
\text { portable reading } \\
\text { devices, but } \\
\text { also signed up } \\
\text { for } 1300+\text { titles } \\
\text { from } \\
\text { netLibrary.com } \\
\text { (Gibbs } \\
\text { 1999-2000) to }\end{array}$ & $\begin{array}{l}\text { Libraries need not stock } \\
\text { or manage any special } \\
\text { hardware (Tennant 2000). } \\
\quad \text { Both local and remote } \\
\text { users have access (Albanese } \\
\text { 2000b; Gibbs 1999-2000). } \\
\quad \text { Eliminates the need for } \\
\text { staff to perform some } \\
\text { cataloguing and circulation } \\
\text { tasks, (Albanese 2000b; } \\
\text { Gibbs 1999-2000). }\end{array}$ \\
\hline
\end{tabular}


2000; Marcinko 2000) . As outlined in Table 1 the netLibrary service allows libraries to purchase e-books that can be lent to their patrons for specified period but with heavily restricted printing out or copying options. Additionally, netLibrary has now acquired peanutpress.com, which specialises in providing electronic books for hand-held devices including PDAs. This gives libraries the option of combining this with the hardware-based model giving a more comprehensive/flexible service (Balas 2000) . be read on the library's or users' desktop computers or laptops. She reports that this proved to be a useful and service to the reading devices.<smiles>C1CCC1</smiles>
(2000) reports on trials at the University of Texas, which has access to over 20,000 scholarly

e-books readable over the web and accessed through the University (online). Library Service via e-book vendors netLibrary and ITKnowledge (General

Libraries 2000) .

E-books received steady usage (higher than their print counterparts); were included in the online catalogue and were well received by clients.
The decision-making process for acquisition is time-consuming given the technical, licencing and access issues that have to be negotiated (Flowers 1999) .

Concern re costs and pricing structure (O'Leary 1999) with ongoing access fees in addition to purchase costs.

Printing and copying options are heavily restricted - Limited by available content.

Appendix III: Table 3: Problems identified from trials of use of reading devices in public and academic libraries:

\begin{tabular}{|l|l|l|l|}
\hline $\begin{array}{l}\text { Problem } \\
\text { Area }\end{array}$ & Issue & Examples & Source \\
\hline Technological & Standards & $\begin{array}{l}\text { Lack of standards resulting in the } \\
\text { need for some library users having to } \\
\text { check out more than one type of } \\
\text { device to read all the titles they } \\
\text { required }\end{array}$ & $\begin{array}{l}\text { (Gibbs } \\
1999-2000)\end{array}$ \\
\hline
\end{tabular}




\begin{tabular}{|c|c|c|c|}
\hline & $\begin{array}{l}\text { Considerable amount of effort had to } \\
\text { be put into converting e-texts into } \\
\text { e-books which were device } \\
\text { independent }\end{array}$ & $\begin{array}{l}\text { (Dillon } 2000 \text {; } \\
\text { Morgan 1999) }\end{array}$ \\
\hline & Memory size & $\begin{array}{l}\text { Devices lacked sufficient memory to } \\
\text { download the advertised number of } \\
\text { titles if all selected titles were long } \\
\text { requiring the need for calculators and } \\
\text { juggling of titles between different } \\
\text { devices. }\end{array}$ & $\begin{array}{l}\text { (Gibbs } \\
1999-2000)\end{array}$ \\
\hline & $\begin{array}{l}\text { Downloading } \\
\text { methods }\end{array}$ & $\begin{array}{l}\text { Varied between makes of devices } \\
\text { some use a computer, some use an } \\
\text { analogue phone line. }\end{array}$ & $\begin{array}{l}\text { (Gibbs } \\
1999-2000)\end{array}$ \\
\hline & $\begin{array}{l}\text { Display quality } \\
\text { and support for } \\
\text { graphics }\end{array}$ & $\begin{array}{l}\text { Users had reservations about the } \\
\text { clarity of the screen definition and the } \\
\text { inability to read graphs, charts and } \\
\text { pictures. }\end{array}$ & $\begin{array}{l}\text { (Gibbs } \\
1999-2000) .\end{array}$ \\
\hline \multirow[t]{10}{*}{$\begin{array}{l}\text { Library Policy } \\
\text { and Procedure }\end{array}$} & \multirow[t]{5}{*}{ Acquisition } & $\begin{array}{l}\text { Protracted negotiations needed for } \\
\text { licence arrangements for Softbooks }\end{array}$ & $\begin{array}{l}\text { (Cline 2000 ; } \\
\text { Gibbs } \\
\text { 1999-2000), }\end{array}$ \\
\hline & & $\begin{array}{l}\text { Each title required had to be } \\
\text { purchased for a specific device. } \\
\text { Hence the need to purchase different } \\
\text { makes of device to offer the widest } \\
\text { range of content }\end{array}$ & $\begin{array}{l}\text { (Gibbs } \\
\text { 1999-2000; } \\
\text { Tennant 2000) }\end{array}$ \\
\hline & & $\begin{array}{l}\text { Credit card payment methods didn't } \\
\text { conform to library practices. Vendor } \\
\text { uncertainty in dealing with library } \\
\text { requests resulted in delivery delays }\end{array}$ & (Cline 2000) \\
\hline & & $\begin{array}{l}\text { Inconvenience of downloading titles } \\
\text { for owners of multiple reading } \\
\text { appliances each device had to have } \\
\text { its own email account. }\end{array}$ & (Burk 2000) \\
\hline & & $\begin{array}{l}\text { Buying titles and loading them onto } \\
\text { individual devices took some } \\
\text { tweaking and required input from both } \\
\text { systems and acquisition staff }\end{array}$ & $\begin{array}{l}\text { (Cline 2000; } \\
\text { Gibbs } \\
\text { 1999-2000), }\end{array}$ \\
\hline & \multirow[t]{2}{*}{ Cataloguing } & $\begin{array}{l}\text { Staff needed to view all the e-books in } \\
\text { order to catalogue them to as the } \\
\text { vendor's listings were inadequate }\end{array}$ & $\begin{array}{l}(\text { Gibbs } \\
1999-2000)\end{array}$ \\
\hline & & $\begin{array}{l}\text { Cataloguing procedures had to be } \\
\text { adapted so that patrons could } \\
\text { determine easily which titles were on } \\
\text { which reader }\end{array}$ & (Burk 2000) \\
\hline & \multirow[t]{3}{*}{ Circulation } & $\begin{array}{l}\text { Physical problems with the devices } \\
\text { and their accompanying accessories } \\
\text { needing to be issued in bags and } \\
\text { requiring time-consuming checks } \\
\text { every time they went in or out }\end{array}$ & $\begin{array}{l}\text { (Burk 2000: } \\
\text { Gibbs } \\
\text { 1999-2000) }\end{array}$ \\
\hline & & $\begin{array}{l}\text { Need for insurance and statement of } \\
\text { user responsibility }\end{array}$ & (Cline 2000) \\
\hline & & $\begin{array}{l}\text { Need to balance clients gaining } \\
\text { advantage from the device's mass } \\
\text { storage ability against rotating them to }\end{array}$ & (Burk 2000) \\
\hline
\end{tabular}




\begin{tabular}{|l|l|l|l|}
\multicolumn{2}{l}{} & waiting patrons. & \\
$\begin{array}{l}\text { Human } \\
\text { Factors }\end{array}$ & $\begin{array}{l}\text { Uess than happy with need to utilise } \\
\text { more than one device to read all } \\
\text { required titles }\end{array}$ & $\begin{array}{l}\text { (Gibbs } \\
1999-2000)\end{array}$ \\
\cline { 2 - 3 } & $\begin{array}{l}\text { Staff } \\
\text { users how to locate titles and how to } \\
\text { troubleshoot devices }\end{array}$ & (Burk 2000) \\
\hline & $\begin{array}{l}\text { Change of staff roles from shelving to } \\
\text { reghosting and reloading electronic } \\
\text { books on devices. }\end{array}$ & (Gibbs \\
\hline
\end{tabular}

\section{F. List of References}

Albanese, A. (2000a). "UVA library's free e-books a success." Library Journal 125(19), p.14- (online). Retrieved March 4, 2001 from ProQuest (database). Bell \& Howell.

Albanese, A. (2000b). "The e-book enterprise: netLibrary's digital mission." Library Journal 125(3), pp.126-128 (online). Retrieved March 5, 2001 from ProQuest (database). Bell \& Howell.

Anon (2000?). Electronic reader software, (Web page). Electronic Book Evaluation Project. Retrieved April 21, 2001 from the World Wide Web:

http://www.rrlc.org/ebook/software.htm

Anon (1999a). "eBooks on the way." Business Asia 7(22), p.4- (online).

Retrieved February 18, 2001 from InfoTrac Web: Expanded Academic ASAP Int'I $E d$. (database). IAC, Vendor: Gale Group, daily updating.

Anon (1999b). "Blackwell's teams with netLibrary." Information Today 16(8), p.56- (online). Retrieved March 4, 2001 from ProQuest (database). Bell \& Howell.

Anon (2000). "E-textbooks hit colleges." Curriculum Review 40(3), p.5(online). Retrieved February 18, 2001 from InfoTrac Web: Expanded Academic ASAP Int'l Ed. (database). IAC, Vendor: Gale Group, daily updating.

Anon (2001a). "Book buyers still prefer the real thing." The Writer 114(1), p.10- (online). Retrieved February 18, 2001 from InfoTrac Web:

Expanded Academic ASAP Int'I Ed. (database). IAC, Vendor: Gale Group, daily updating.

Anon (2001b). "Electronic books in libraries: Rights of libraries and publishers." Information Outlook 5(2), p.37- (online). Retrieved March 4, 2001 from ProQuest (database). Bell \& Howell.

Ardito, S. (2000). "Electronic books: To "e" or not to "e"; that is the question." Searcher 8(4), pp.28-39 (online). Retrieved March 3, 2001 from the World Wide Web: 
http://www.infotoday.com/searcher/apr00/ardito.htm

Balas, J. I. (2000). "Developing library collections for a wired world." Computers in Libraries 20(6), p.61- (online). Retrieved February 18, 2001 from InfoTrac Web: Expanded Academic ASAP Int'l Ed. (database). IAC, Vendor: Gale Group, daily updating.

Barnard, S. B. (1999). "Libraries and e-books: Opportunities and issues." Future of Print Media Journal (Spring), (online). Retrieved February 10, 2001 from the World Wide Web

http://www.futureprint.kent.edu/articles/barnard01.htm

Breeding, M. (2000). "NetLibrary, innovative interfaces to add e-books to library collections." Information Today 17(4), pp.1-3 (online). Retrieved March 7, 2001 from ProQuest (database). Bell \& Howell.

Bryant, E. (2000). "E-book summit highlights progress, but slights libraries." Library Journal 125(18), pp.12-13 (online). Retrieved March 5, 2001 from ProQuest (database). Bell \& Howell.

Burk, R. (2000). "Don't be afraid of e-books." Library Journal 125(7), p.42(online). Retrieved February 18, 2001 InfoTrac Web: Expanded Academic ASAP Int'l Ed. (database). IAC, Vendor: Gale Group, daily updating.

Chaiken, D., Hayter, M.; Kistler, J. \& Redell, D. (1998). The Virtual book. SRC Research Report.157 (online). Retrieved January 26, 2001 from the World Wide Web:

http://gatekeeper.dec.com/pub/DEC?SRC/research-reports/abstracts/src-rr157.html

Cline, L. (2000). "Buying electronic: the development of the electronic book market in academic libraries." Library Collections, Acquisitions, and Technical Services 24(2), pp.312-315 (online). Retrieved March 3, 2001 from ScienceDirect (database). Elsevier, daily updating.

Coyle, K. (2000). "Change, change, change: libraries and the future." The Australian Library Journal 49(1), pp27-30.

Crawford, W. (2000). "Nine models, one name: Untangling the e-book muddle." American Libraries 31(8), p.56- (online). Retrieved February 12, 2001 from InfoTrac Web: Expanded Academic ASAP Int'l Ed. (database). IAC, Vendor: Gale Group, daily updating.

Darnton, R. (1989). What is the history of books? In Reading in America. ed. C. N. Davidson. John Hopkins University: Baltimore.

Darnton, R. (1999). "The new age of the book." The New York Review of Books (March 18), (online). Retrieved May 14, 1999 from the World Wide 
Web:

http://www.nybooks.com/nyrev/WWWfeatdisplay.cgi?19990318005f

Dillon, D. (2000). A two year journey with e-books: The University of Texas Experience, (Web page). The General Libraries: The University of Texas at Austin. Retrieved February 26, 2001 from the World Wide Web:

http://www.lib.utexas.edu/cird/principles.html

Ditlea, S. (2000). "The real e-books." Technology Review 103(4), p.70(online). Retrieved February 18, 2001 from InfoTrac Web: Expanded Academic ASAP Int'l Ed. (database). IAC, Vendor: Gale Group, daily updating.

Dorman, D. (1999). "The e-book: pipe dream or potential disaster?" American Libraries 30(2), p.36- (online). Retrieved February 23, 2001 from InfoTrac Web: Expanded Academic ASAP Int'l Ed. (database). IAC, Vendor: Gale Group, daily updating.

Ferguson, S. (1994). INF401 Information Society: Module 1. Charles Sturt University: Wagga Wagga, NSW.

Fialkoff, F. (2000). "Where's the library model?" Library Journal 125(13), p.78- (online). Retrieved March 4, 2001 from ProQuest (database). Bell \& Howell.

Fiander, M. (2000). "Bringing eMonographs into the digital library: A report of an ALCTS preconference." Library Collections, Acquisitions, and Technical Services 24(2), pp. 274-276 (online). (3 Mar. 2001). Retrieved March 3, 2001 from ScienceDirect (database). Elsevier, daily updating.

Flowers, J. L. (1999). "netLibrary.com: Cautious optimism / views from a research library and a university press." Against the Grain 11(5), p.22 \& p. 24.

General Libraries, The University of Texas at Austin (2000). E-books update \& future plans. Library News (August), (online). Retrieved February 26, 2001 from the World Wide Web:

http://www.lib.utexas.edu/About/news/librarynews10.html

Gibbs, N. (1999-2000). "E-books: Report on an ongoing experiment." Against the Grain 11(6), pp.23-25.

Greiner, L. (2000). "PDAs are perfect for e-books." Computing Canada 26(8), p.18- (online). Retrieved March 7, 2001 from ProQuest (database). Bell \& Howell.

Hawkins, D. T. (2000). "Electronic books: a major publishing revolution." 
Online 24(4), pp.14-28 (online). Retrieved February 17, 2001 from ProQuest (database). Bell \& Howell.

Kirkpatrick, D. D. (2000). The struggles over e-books abound, though readership remains elusive. New York Times (Nov 27), (online). Retrieved March 4, 2001 from ProQuest (database). Bell \& Howell.

Kristl, C. ed. (2000). "Should libraries jump on the e-book bandwagon? (interview)." American Libraries 31(7), p.61- (online). Retrieved February 12, 2001 from InfoTrac Web: Expanded Academic ASAP Int'l Ed. (database). IAC, Vendor: Gale Group, daily updating.

Lamont, M. (1999). "Critical human factors in emerging library technology centers." Library Hi Tech 17(4), pp.390-395.

Landoni, M. \& Gibb, F. (2000). "The role of visual rhetoric in the design and production of electronic books: The visual book." The Electronic Library 18(3), pp.190-201 (online). Retrieved March 18, 2001 from ProQuest (database). Bell \& Howell.

Landoni, M., Wilson, R. \& Gibb, F. (2000). "From the Visual book to the WEB book: The importance of design." The Electronic Library 18(6), pp.407-419 (online). Retrieved March 18, 2001 from ProQuest (database). Bell \& Howell.

Lonsdale, R. E. \& Armstrong, C. J. (2000). "Electronic scholarly monographs: Issues and challenges for the UK." Learned Publishing 13(1), 15-24 (online). Retrieved March 29, 2001 from the World Wide Web:

http://www.alpsp.org.uk/journal.htm

Lynch, C. (1999). "Electrifying the book." Library Journal (Oct 15), pp.3-6 (online). Retrieved March 4, 2001 from ProQuest (database). Bell \& Howell.

Maack, I. (2001). "The ebook phenomenon: Is print dead?" internet.au (64), pp58-63.

Marcinko, D. K. (2000). "Collecting the ebook: a report on the ALCTS/CMDS collection development librarians of academic libraries discusssion group." Library Collections, Acquisitions, and Technical Services 24(2), pp.303-304 (online). Retrieved March 3, 2001 from ScienceDirect (database). Elsevier, daily updating.

Mercer, L. (2000). "Measuring the use and value of electronic journals and books." Issues in Science and Technology Librarianship (Winter), (online). Retrieved February 26, 2001 from ScienceDirect (database). Elsevier, daily updating. 
Messing, J. (1995). Measuring student use of electronic books. In Learning with technology. 11th Annual Conference of the Australian Society for Computers in Learning in Tertiary Education, eds. J. M. Pearce and A. Ellis. The Science Multimedia Teaching Unit, Faculty of Science, The University of Melbourne for the Australian Society for Computers in Learning in Tertiary Education (ASCILITE): Melbourne, pp.417-424.

Minkel, W. (1999). "E-books zapping their way to library network." School Library Journal 45(11), p.18 (online). Retrieved March 7, 2001 from ProQuest (database). Bell \& Howell.

Minkel, W. (2000). "The e-textbooks are coming." School Library Journal 46(9), p.18- (online). Retrieved March 3, 2001 from ProQuest (database). Bell \& Howell.

Morgan, E. L. (1999). "Electronic books and related technologies." Computers in Libraries 19(10), pp.36-39 (online). Retrieved February 17, 2001 from ProQuest (database). Bell \& Howell.

netLibrary (2000-2001). The netLibrary eBook reader, (Web page). netLibrary. Version 18 Apr. 2001 quoted. Retrieved April 18, 2001 from the World Wide Web:

http://www.netlibrary.com/nl_ebook_reader.asp

Nuvomedia (2001). "eBookNet Poll Results: Handheld editions of eBookNet?" eBookNet Weekly News 3(11), ebook.com listserv (news@ebooknet.com) document, dated March 16, 2001.

O'Leary, M. (1999). "NetLibrary: The virtual library arrives?" Information Today 16(8), pp.15-16 (online). Retrieved March 4, 2001 from ProQuest (database). Bell \& Howell.

Peters, T. (2000). Charleston Conf. notes re: e-books, (Newsgroup). Posted as message number 72 by Hoeth, Kathleen on Nov 10 th 2000 to news group swfln. Version 21 Apr. 2001.

http://groups.yahoo.com/groups/swfln/message/72

Quint, B. (2000). "NetLibrary offers 1,500 e-book titles to 100 large public libraries in trial program." Information Today 17(3), pp.18-19 (online). Retrieved March 7, 2001 from ProQuest (database). Bell \& Howell.

Rogers, M. (2000a). "Innovative Interfaces Inc. Adding netLibrary's eBooks." Library Journal 125(6), p.27 (online). Retrieved February 18, 2001 from InfoTrac Web: Expanded Academic ASAP Int'l Ed. (database). IAC, Vendor: Gale Group, daily updating.

Rogers, M. (2000b). "FL libraries to get e-book access." Library Journal 125, p.16- (online). Retrieved February 18, 2001 from InfoTrac Web: 
Expanded Academic ASAP Int'I Ed. (database). IAC, Vendor: Gale Group, daily updating.

Schilit, B. (1999). "Why e-read? Finding opportunites in the merger of paper and computers." Future of Print Media Journal (Spring), (online). Retrieved February 10, 2001 from the World Wide Web:

http://www.futureprint.kent.edu/articles/schilit01.htm

Simon, E. J. (2001). "Electronic textbooks: A pilot study of student e-reading habits." Future of Print Media Journal (Winter), (online). Retrieved February 10, 2001 from the World Wide Web:

http://www.futureprint.kent.edu/articles/simon01.htm

Sottong, S. (1999). "Don't power up that E-book just yet." American Libraries 30(5), pp.50-54 (online). Retrieved February 18, 2001 from InfoTrac Web: Expanded Academic ASAP Int'l Ed. (database). IAC, Vendor: Gale Group, daily updating.

Summerfield, M.\& Mandel, C. A. (1999). On-line books at Columbia: Early findings on use, satisfaction and effect. In Technology and Scholarly Communication. ed. R. Ekman and R. E. Quandt. University of California Press in Association with the Andrew W. Mellon Foundation: Berkeley, pp.282-308.

Tennant, R. (2000). "The emerging role of e-books." Library Journal 125(13), p.38- (online). Retrieved February 18, 2001 from InfoTrac Web: Expanded Academic ASAP Int'l Ed. (database). IAC, Vendor: Gale Group, daily updating.

Terry, A. A. (1999). "Demystifying the e-book: What is it, where will it lead us, and who's in the game?" Against the Grain 11(Nov), p.18,\&p. 20.

Wearden, S. (1998). "Electronic books: A study of potential features and their perceived value." Future of Print Media Journal (Fall), (online). Retrieved February 10, 2001 from the World Wide Web:

http://www.futureprint.kent.edu/articles/wearden02.htm

Williamson, K. (2000). Research methods for students and professionals: Information management and systems. Centre for Information Studies: Wagga Wagga NSW. 